Marcin KOTRAS

Uniwersytet Łódzki

kotras@o2.pl

\title{
KONSTRUOWANIE \\ RZECZYWISTOŚCI POLITYCZNEJ
}

\author{
ANALIZA OKŁADEK TYGODNIKÓW \\ „UWAŻAM RZE” I „POLITYKA”
}

ABSTRACT Political reality constructing. „Uważam Rze” and „Polityka” weekly magazines covers analysis

The article presents the results of semiotic analysis conducted for 78 weekly socio-political magazines covers: „Uważam Rze” and „Polityka”. The research was connected with the problem of presenting and constructing the political reality on the covers of the magazines. It was assumed, that each of analysed titles functions in a contrary scopic regime and, as a consequence, presents different images of politics. The article is also an attempt to answer the questions: Which signs were used in constructing the political reality? In which way politicians activities were commented on the magazines covers? What kind of references to value systems and to social and political divisions were presented on the covers? The remarks concerning knowledge transmission and social worlds formation centered around magazines are also described in the paper. Synthesis of research outcomes is presented in article summary.

Keywords: „Polityka”, „Uważam Rze”, the image of reality

Słowa kluczowe: „Polityka”, „Uważam Rze”, obraz rzeczywistości 


\section{1. ŹRÓDŁA TEORETYCZNE}

Problematyzacja kluczowych kwestii w artykule jest zgodna ze stanowiskiem Petera Bergera i Thomasa Luckmanna, którzy zakładają, iż rzeczywistość tworzona jest społecznie. Ponadto ma ona charakter intersubiektywny, co oznacza, że [...] świat życia codziennego jest dla innych tak samo rzeczywisty jak dla mnie [...] że między moimi znaczeniami i ich znaczeniami $w$ tym świecie istnieje nieustanna odpowiedniość, że dzielimy wspólny sens, w jakim jest on rzeczywisty ${ }^{1}$. Wspomniani autorzy odnoszą się również do wiedzy, którą traktują m.in. jako zobiektywizowane znaczenia działalności instytucjonalnej. Do uznania wiedzy, jej przyjęcia i przekazywania istotne jest funkcjonowanie aparatu społecznego zapewniającego jej transmisję. Niemniej jednak instytucje i osoby dokonujące owych transmisji stosują określone procedury kontrolne i uprawomocniające. Od charakteru tych procedur i ich funkcjonalności zależeć będzie to, na ile transmitowana wiedza jawi się jako spójna logicznie i które spośród często skonfliktowanych przekazów (transmisji) zostaną przyswojone i zaakceptowane (włączone w strategie opisu rzeczywistości) przez odbiorców w procesie socjalizacji². W badaniu przyjęto założenie, że instytucjami dokonującymi transmisji wiedzy są nadawcy medialni, wśród nich zaś tygodniki społeczno-polityczne.

Kolejną podstawę prowadzonych w artykule rozważań stanowią tezy Maxwella McCombsa i jego teoria ustalania porządku dnia (agenda setting) $)^{3}$, zgodnie z którą to nadawcy medialni poprzez określony dobór i układ publikowanych informacji i materiałów kształtują formę oraz treść agendy publicznej. W tym przypadku, odwołując się do stwierdzenia Roberta Parka, mamy do czynienia z wprowadzaniem informacji, traktowanej jako forma wiedzy ${ }^{4}$ (news as a form of knowledge). McCombs zwraca ponadto uwagę na standardy retoryczne w dziennikarstwie, przywołując jedną z często używanych przez dziennikarzy językowych klisz ludzie maja prawo wiedzieć. Nadawca przypisuje tu sobie rolę strażnika praw wspólnoty, zapewniając jej członkom prawo do bycia poinformowanym. Trudno jednak rozstrzygać, dlaczego ludzie mają prawo wiedzieć akurat to, co dziennikarz chce im przekazać. Okładki badanych tygodników traktowane były jako część medialnego dyskursu mającego wpływ na kształt agendy publicznej. Założono, że przy ich pomocy nadawcy dokonują „ramowania” rzeczywistości, oddziałując przez to na dobór i interpretację kluczowych problemów społecznych i politycznych.

Dokonując rekapitulacji tych wstępnych ustaleń, można stwierdzić, że badanie odwoływało się do opisu i konstruowania rzeczywistości politycznej w znaczeniu „sytu-

P. Berger, T. Luckmann, Społeczne tworzenie rzeczywistości. Traktat z socjologii wiedzy, przeł. i przedm. J. Niżnik, Warszawa 2010, s. 37, Biblioteka Socjologiczna.

2 Tamże, s. 105.

3 M. McCombs, Ustanawianie agendy. Media masowe i opinia publiczna, przeł. B. Radwan, Kraków 2008, s. 1-21, Media - Wydawnictwo Uniwersytetu Jagiellońskiego.

4 R. E. Park, News As a Form of Knowledge: A Chapter in the Sociology of Knowledge, „The American Journal of Sociology" 1940, Vol. 45, nr 5, s. 669-686. 
acji społecznych" (konstrukcjonizm). Głównym jego celem był opis działań i strategii podejmowanych przez nadawców medialnych, związanych z wytwarzaniem sytuacji, integrowaniem środowisk (skupionych np. wokół określonych wartości) i organizowaniem określonego typu ładu społecznego. Inaczej mówiąc, chodziło o ustalenie, w jaki sposób tygodniki proponują swoim czytelnikom prawidłowe rozumienie i odtwarzanie rzeczywistości politycznej, a także o to, jak dokonuje się za ich pośrednictwem transmisja wiedzy.

Okładki tygodników potraktowano jak naturalnie pojawiające się dane do badania (naturally occuring data); badacz nie ma wplywu na proces ich powstawania 5 . Ponadto, zgodnie z dyspozycjami na gruncie socjologii wizualnej, uznano je za listę tematycznych obrazów, które w toku prowadzonej analizy zmieniają się w listę tematów i pytań - mogą one zostać sformułowane w celu poszukiwania pewnych wzorców w tych materiałach i budowania na tej podstawie określonych sądów na temat rzeczywistości społecznej ${ }^{6}$. Należy również pamiętać, że analizy danych wizualnych (podobnie jak inne formy socjologicznych dociekań) są zależne od perspektywy badacza oraz kontekstu badania. Dlatego opisywane w artykule badanie nie rości sobie praw do uniwersalności, ale jest jedynie egzemplifikacją odnoszącą się do zakwalifikowanego do badania materiału.

\section{OPIS METODOLOGII BADANIA}

Do badania jako materiał źródłowy, stanowiący w konsekwencji korpus badawczy, wybrano okładki dwóch tygodników społeczno-politycznych: „Polityki” i „Uważam Rze”. Dobór analizowanych okładek nie był związany z żadnym konkretnym kryterium. Wybrano 40 kolejnych numerów tych czasopism, poczynając od numeru 1 w 2012 r. i kończąc na numerze 40. Dało to łącznie 78 okładek (w każdym z tygodników jeden numer miał charakter podwójny). Pierwszy etap badania polegał więc na gromadzeniu materiałów, co wiązało się z zakupem kolejnych numerów tygodników i archiwizacją ich okładek.

Za cel badania przyjęto opis działań i strategii podejmowanych przez wybranych nadawców medialnych, związanych z transmisją określonego typu wiedzy i tym samym wizji świata prezentowanej swoim odbiorcom (czytelnikom). Przedmiotem badania były znaki (symbole) oraz tekst pojawiające się na okładkach tygodników. Problematyka badawcza koncentrowała się wokół kwestii związanych z reżimem skopicznym, czyli kulturowym konstruowaniem tego, co widziane. Założono, że proces ten będzie odmienny w przypadku badanych tytułów.

Po zgromadzeniu i archiwizacji okładek przystąpiono do procedury ich kodowania. Odbywało się ono w sposób otwarty (zgodnie z indukcyjnym modelem analiz),

5 D. Silverman, Interpretacja danych jakościowych. Metody analizy rozmowy, tekstu i interakcji, przeł. M. Głowacka-Grajper, J. Ostrowska, wprow. K. T. Konecki, Warszawa 2007, s. 330.

$6 \quad$ K. T. Konecki, Wizualne wyobrażenia. Gtówne strategie badawcze w socjologii wizualnej a metodologia teorii ugruntowanej, „Przegląd Socjologii Jakościowej” 2005, t. 1, nr 1, s. 43-44. 
czyli nie założono na wstępie kategorii, do których kwalifikowane były poszczególne okładki. Dopiero po ich opisie i wyszczególnieniu określonego instrumentarium symbolicznego używanego przez nadawców wyodrębniono i nazwano kategorie, do których przypisano poszczególne okładki. Dodać w tym miejscu należy, że ze względu na polisemiczność znaków i nasycenie symboliką okładek czasopism dopuszczalną sytuacją w procedurze kodowania i kategoryzowania było zakwalifikowanie tej samej okładki do więcej niż jednej kategorii. Jednak mimo owej polisemiczności można mówić o tzw. znaczeniach preferowanych. Ma to związek z procesem internalizacji treści kultury, dominującym ładem kulturowym i pozwala na wpisanie tego, co nowe, obserwowane, w istniejące mapy problematyki spotecznej ${ }^{7}$. Wiąże się to również z narzucaniem określonego stanowiska odnoszącego się do porządku kulturowego akceptowanego przez nadawcę. Sfera znaczeń konkretnego znaku przybiera zatem strukturę hierarchiczną.

W kolejnym etapie dokonano procesu agregacji wyodrębnionych kilkunastu kategorii, zmniejszając ich liczbę do dwóch. Proces ten odbywał się przez poszukiwanie jak najszerszych obszarów tematycznych, grupujących kodowane treści i znaczenia. Uznano, że nadmierna liczba kategorii uczyni analizę mocno fragmentaryczną i rozczłonkowaną, stąd ostatecznie wyodrębnione zostały następujące dwie:

Ocena funkcjonowania państwa, działań obozu rządzącego i prowadzonej przez niego polityki - zaliczono tu okładki, które odnoszą się do: oceny premiera, ministrów rządu, opisu procesu decyzyjnego w państwie, podejmowanych projektów i reform, roli i działań opozycji, relacji na linii rządzący-rządzeni, mechanizmów rządzących współczesną polityką i kulis władzy, zwłaszcza na poziomie krajowym i europejskim (relacje zewnętrzne Polski, charakterystyka Unii Europejskiej i jej państw członkowskich), komentarzy na temat katastrofy smoleńskiej.

Nowe podziały socjopolityczne, tożsamościowe i aksjologiczne we współczesnym polskim społeczeństwie - zaliczono tu okładki odnoszące się do starych i nowych form podziałów socjopolitycznych (kwestia wartości i stylu życia), wartości religijnych, form i kształtowania się tradycyjnych i nowych ról społecznych, stosunku do kategorii „polskości”, resentymentu narodowego, roli mediów w procesie kształtowania środowiska kulturowego, podziałów w obrębie świata mediów i relacji w środowisku dziennikarskim.

Następnie przystąpiono do właściwej analizy okładek, w pierwszym etapie koncentrując się na tzw. diegezie, czyli opisie sumy denotatywnych znaczeń. W praktyce polegało to na opisie tego, co na okładce zostało zaprezentowane. Były to zdjęcia (mające być bezpośrednią lub metaforyczną reprezentacją określonego problemu, zjawiska czy idei), fotomontaż (wykorzystujący kilka fotografii lub będący wynikiem ingerencji osoby „obrabiającej” zdjęcie) lub grafika-rysunek (nawiązujący do prezentowanego w numerze głównego tematu). Dokonano szczegółowego opisu, opierając się na technice zgodnej z semiologiczną analizą obrazów. Koncentrowała się ona na odpowiedziach na pytania: Jak obrazy tworzą znaczenia? Jak dany wizerunek funkcjonuje w stosunku do

S. Hall, Kodowanie i dekodowanie, „Przekazy i Opinie” 1987, nr 1-2, s. 66. 
systemów znaczeniowych w szerszym zasięgu? Założono tym samym, że określona formacja społeczna obecna jest w samym obrazie ${ }^{8}$. Analiza nie dotyczyła więc kwestii zideologizowanej wiedzy prezentowanej na okładkach, ale tego, w jaki sposób dokonywano (re)konstrukcji bieżących wydarzeń i problemów politycznych. W opisie okładek uwzględniano przede wszystkim modalności: kompozycyjną i społeczną (odnoszącą się do zgodnego z intencją nadawcy społecznego odbioru okładki). Okładkę tygodnika traktowano w badaniu nie tylko jako zapowiedź głównego tematu i tematów pobocznych w numerze, ale również jako przekaz o charakterze reklamowym, mający zachęcić zadeklarowanego lub potencjalnego czytelnika do zakupu tygodnika.

W badaniu oparto się na założeniach semiotyki Charlesa Peirce’a, głównego przedstawiciela pragmatyzmu w filozofii. Kierunek ten poszukuje metody ustalenia rzeczywistego znaczenia każdego pojęcia, doktryny, zdania, słowa czy innego znaku' . Dla pragmatyzmu charakterystyczna jest również abdukcja, czyli [...] metoda tworzenia ogólnych przewidywań, bez żadnej bezwzględnej pewności, że zostanq one potwierdzone, czy to powszechnie, czy tylko w jakimśszczególnym przypadku. Za swe uzasadnienie to ma jedynie, że tylko ona daje nadzieje na racjonalne kierowanie naszymi przysztymi zachowaniami, i jeszcze to, że wnioski indukcyjne ptynace z minionych doświadczeń każa nam wierzyć, że owa metoda będzie skuteczna także w przysztości $i^{10}$.

Chodzi zatem o dedukcyjne ustalanie praktycznych konsekwencji hipotez i ich indukcyjne sprawdzanie.

W badaniu nie znalazły się odniesienia do rozbudowanej klasyfikacji znaków zaproponowanej przez Peirce’a, która może stać się podstawą do szerokich analiz dyskursywnych i logicznych. Wykorzystana została ta część rozważań filozofa, która odnosi się do relacji między nośnikiem znaczenia a znakiem. Peirce odróżnia denotację aplikatywną znaku od jego funkcji przedstawieniowej. Znak nie jest więc czymś, co jawi się jedynie w sposób realny, ale jest przede wszystkim symbolem, który pośredniczy w procesie poznania. Znak w ujęciu tym staje się de facto relacją triadyczną, w skład której wchodzą: przedmiot-znak-interpretant. Znak zastępuje swój przedmiot, zaś interpretant to znaczenie znaku. Sposób zastosowania analizy semiotycznej w badaniu jest oparty na propozycji Gillian Rose ${ }^{11}$. Kluczowe w tym przypadku jest powiązanie znaku z przedmiotem. Wyróżniamy zatem:

- ikony (znaki ikoniczne) - kiedy znaczące jest reprezentacją znaczonego; jeśli coś funkcjonuje na zasadzie naturalnego, strukturalnego podobieństwa (fotografia mojego przyjaciela jest jego znakiem, ikoną właśnie);

- znaki indeksowe (wskaźniki, oznaki) - gdy związek między znaczonym a znaczącym jest zdeterminowany kulturowo, przez co jawi się jako „naturalny” czy

8 G. Rose, Interpretacja materiatów wizualnych. Krytyczna metodologia badań nad wizualnościa, przeł. E. Klekot, Warszawa 2010, s. 103, Metodologia - Wydawnictwo Naukowe PWN.

9 T. Gadacz, Historia filozofii XX wieku. Nurty, t. 1: Filozofia życia, pragmatyzm, filozofia ducha, Kraków 2010, s. 239-241.

10 Ch. S. Peirce, Wybór pism semiotycznych, Warszawa 1997, cyt. za: T. Gadacz, dz. cyt., s. 243.

11 G. Rose, dz. cyt., s. 111. 
„właściwy”; podstawa owej relacji może mieć też charakter przyczynowy bądź rzeczowy (znaki drogowe, język ciała);

- symbol - gdy relacja znaczący-znaczony ma charakter skonwencjonalizowany, opierający się na określonej umowie i regułach, co nie wyklucza jednocześnie jego arbitralności (zdjęcie płaczącej kobiety z ciałem mężczyzny, być może jej męża, jako prezentacja okrucieństwa wojny).

W sytuacji, gdy było to możliwe i zasadne dla wzbogacenia opisu i interpretacji, analiza została uzupełniona o wskazanie na okładkach znaków paradygmatycznych (uzyskujących znaczenie dzięki skontrastowaniu ich z innymi znakami, np. kobieta na fotografii to nie mężczyzna). Wprowadzono również dodatkową klasyfikację koncentrującą się na podziale znaków na: konotatywne (nośniki całej gamy znaczeń; taką funkcję może pełnić plakat propagandowy, np. wizerunek młodego mężczyzny w stroju górnika z kilofem uniesionym ku górze, jako przyszłość, w której młodzi reprezentanci ludu pracującego rozpoczną walkę o swoje), metonimiczne (odwołanie do skojarzeń ze znakiem w nawiązaniu do jego częstej interpretacji, np. fotografia dzieci to przyszłość) i synekdochalne (znak lub jego część, która zastępuje całość, lub całość, która reprezentuje część, np. zdjęcie Rynku Starego Miasta w Krakowie reprezentujące cały Kraków).

Analiza koncentrowała się każdorazowo na dokonywanym przez nadawcę „zakotwiczaniu" przekazu, czyli ukierunkowywaniu i sugerowaniu właściwego odczytania relacji znaczący-znaczony. Wiązało się to głównie z analizą umieszczonego na okładce tekstu i odniesieniem prezentowanych tam znaków do kontekstu politycznego i kulturowego.

Pojęciem spajającym analizę badanego materiału był „kod”, rozumiany jako [...] zespót skonwencjonalizowanych sposobów tworzenia znaczenia, wtaściwy dla określonych grup ludzi $i^{12}$. Umiejętne przeniesienie tego, co jest prezentowane na okładce, na ludzi czy wydarzenia wymaga odpowiednio zakodowania przez nadawcę i odkodowania przez odbiorcę. Istotnym zadaniem było w tym przypadku wyróżnienie tzw. metakodów, czyli kodów dominujących, odnoszących się do rozbudowanych systemów odniesień, często przez dychotomiczne zestawienia (np. natura-kultura). Te z kolei wiążą się z tzw. metaznakami, które są angażowane przez poszczególne grupy społeczne (a za takie można uznać czytelników badanych tytułów) w procesie interpretacji, nie tylko do zrozumienia przekazu, ale i do podkreślenia swojej odmienności. W ten sposób tworzy się więc określony reżim skopiczny organizujący sposób postrzegania świata. U odbiorcy obrazu (okładki gazety) wytwarzają się określone emocje, ale przychodzą one do niego [...] za rozumowym pośrednictwem [...] kultury moralnej i politycznej ${ }^{13}$.

W podsumowaniu artykułu znalazły się również uwagi dotyczące społecznego wytwarzania znaczenia. Dotyczyły one inicjatora tego procesu, czyli mediów. Ważne dla zrozumienia logiki dyskursu politycznego jest rozpoznanie strategii komunikacyjnych, przy pomocy których tygodniki dokonują działań formacyjnych i socjalizujących w stosunku do swych czytelników. Pomocne w tym będzie ustalenie struktury systemu

12 Tamże, s. 122.

13 R. Barthes, Światto obrazu. Uwagi o fotografii, przeł. J. Trznadel, Warszawa 2008, s. 50. 
logonomicznego, który wpływa na reguły i warunki tworzenia znaczeń. Należy jednak w tym miejscu wyraźnie zaznaczyć, że w badaniu tym nie poddano analizie recepcji okładek, pozostając na poziomie ich semiotycznego opisu.

\section{OCENA FUNKCJONOWANIA PAŃSTWA, DZIAŁAŃ OBOZU RZĄDZĄCEGO I PROWADZONEJ PRZEZ NIEGO POLITYKI}

\section{1. „Uważam Rze”}

Rozpoczynając analizę znaków pojawiających się w tej kategorii, należy zwrócić uwagę na zjawisko personalizacji polityki. Charakterystyka stanu instytucji państwowych, prowadzonej polityki czy wdrażanych projektów jest sprowadzana do oceny premiera lub innych wyrazistych postaci (polityków na eksponowanych stanowiskach, ludzi znanych, politycznych i telewizyjnych celebrytów). Zwłaszcza jeden z tygodników, „Uważam Rze”, wielokrotnie ilustruje kwestie związane z funkcjonowaniem państwa przez prezentowanie określonego wizerunku premiera (niekiedy korzystając z opinii zapraszanych do tygodnika popularnych osób, których zdjęcia są na okładce). Posługuje się najczęściej grafiką (rysunkiem) lub fotomontażem.

Tak jest w przypadku nr 1/2012, gdzie posłużono się rysunkiem. Patrzący na okładkę może się domyślać, że przedstawioną na nim postacią jest Donald Tusk (nawiązuje do tego zakotwiczenie: Bez recepty na cud. Za fasada rzekomego sukcesu dojrzewa kleska premiera Tuska). Premier to człowiek z biało-czerwonym parasolem podchodzący do mównicy między dwiema wzburzonymi falami, które zdają się opadać. Okładka nawiązuje do mitu mojżeszowego - lider wspólnoty przeprowadza ją przez wzburzone morze. W tym przypadku jednak za liderem nie ma nikogo. Przechodzi samotnie, chroniąc się pod parasolem. Podobną wymowę ma okładka, na której użyto fotomontażu (nr 16/2012). Zestawiono tam ze sobą dwa rodzaje fotografii: kolorową i czarno-białą. $\mathrm{Na}$ pierwszym planie widzimy przepołowioną głowę premiera, odsłania ,inną” głowę, a w zasadzie twarz Donalda Tuska. Ta „prawdziwa” jest czarno-biała, zaś jej wyraz jest zdecydowanie bardziej ponury, ze spojrzeniem skierowanym w dól. Pod kolorową fasadą ukryta jest więc czarno-biała prawda, realny wizerunek premiera. Symbolika odnosi się do człowieka o dwóch twarzach (motywu niezwykle często wykorzystywanego w przekazach kulturowych, w tym w kulturze popularnej - znak indeksowy dotyczący osób fałszywych, nieszczerych, dwulicowych właśnie). W poprawnym odczytaniu okładki ma również pomóc zakotwiczenie: Utrata mocy. Szef rządu ma problemyz kontrolowaniem sytuacji i samego siebie. Ocena jest zdecydowanie negatywna, nawiązuje do braku panowania nad sobą i sytuacją. Inna z okładek, zaliczona do tej kategorii, kolejny raz jest oceną premiera i jego polityki. To rysunek przedstawiający Tuska z wydłużonym drewnianym nosem (na którym są nawet dwa zielone liście). Symbolika jest tu jednoznaczna, ale - by nie było żadnych wątpliwości - odbiorca otrzymuje zakotwiczenie w postaci tekstu: Donald Pinokio. Ile prawdy, a ile ktamstw $w$ stowach premiera (nr 37/2012). Ukryte w zakotwiczeniu pytanie ma charakter pozorny. Odpowiedzią 
jest bowiem wydłużony nos premiera, zachowujący się tak w przypadku kłamstw jak u bajkowego Pinokio. Znak w tym przypadku ma zarówno charakter indeksowy, jak i symboliczny.
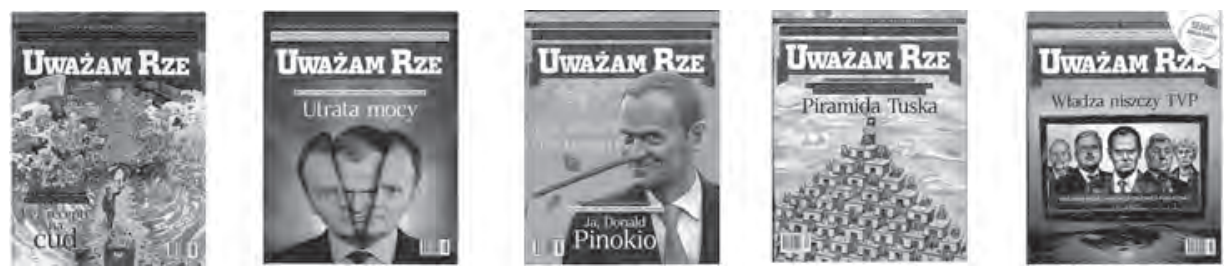

Prezentacja premiera dokonywana jest poprzez odwołanie się do określonego reżimu odbioru, związanego z rozpoznawalnymi przez odbiorcę znakami-symbolami, które jest on w stanie poprawnie zakodować i którym może nadać określone znaczenie zgodne z intencją nadawcy. W podobny sposób „Uważam Rze” prezentuje premiera (i obóz rządzący) na innych okładkach. Jest więc Tusk stojący na czele grupy niszczącej media publiczne (nr 19/2012), a także siedzący przy biurku na szczycie piramidy ustawionej z innych biurek (nr 39/2012), co symbolizuje rozrastający się, hierarchiczny system biurokracji. Zakotwiczeniem w tym przypadku jest tekst: Piramida Tuska. Ile naprawdę kosztuje nas pęczniejaca biurokracja? Ilu ludzi zatrudnit na nasz koszt premier? Ile za to zaptacimy? Warto dodać, że samo sformułowanie Piramida Tuska rezonowało w tym czasie z komunikatami na temat „piramidy finansowej” Amber Gold. Zestawienie tych dwóch „piramid” nie wydaje się niezamierzone.

Do kategorii „ocena funkcjonowania państwa” zaliczono również te okładki, na których znane, publiczne postaci oceniają bieżące wydarzenia społeczne, kulturalne i polityczne. Wizja prezentowana w „Uważam Rze” jest i w tym przypadku jednoznaczna. Na okładkach widzimy fotografie osób patrzące w obiektyw (nawiązanie kontaktu wzrokowego z patrzącym), kluczowe natomiast stają się w tym przypadku tekstowe zakotwiczenia uzupełniające ich wizerunki.
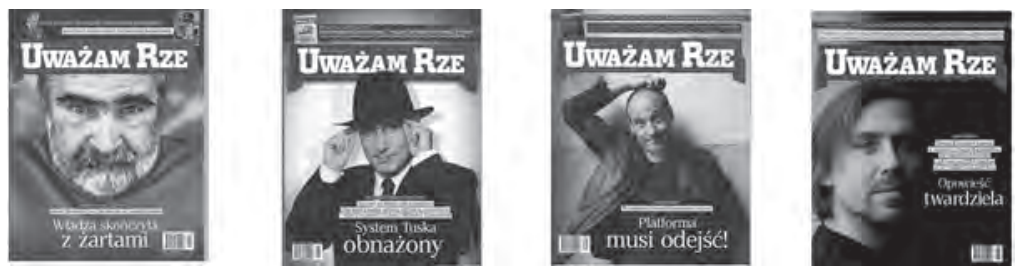

Możemy więc przeczytać, że: Wtadza kończy ż̇artami. Janusz Rewiński o tymjak domyka się medialny system (nr 37/2012); Pawet Kukiz w rozmowie z braćmi Karnowskimi wzywa: Platforma musi odejść (nr 34/2012); Jan Rokita przerywa milczenie. Ten rzad nie stawia czota wyzwaniom. Chce wyjść z opatów sprytem, chytrością i cwaniactwem - mówi w rozmowie z Jackiem i Michatem Karnowskimi. System Tuska obnażony (nr 11/2012); Agent Tomek. Tomasz Kaczmarek ujawnia w rozmowie z braćmi Karnowskimi jak roz- 
pracowat Sawicka i jak nowy SzefCBA rzucit go na pożarcie mediom. Opowieść twardziela (nr 21/2012); Ojciec Tadeusz Rydzyk. Pierwsza taka rozmowa. Z Jackiem i Michatem Karnowskim o Kościele, polityce, Radiu Maryja i Telewizji Trwam. Odważna Polska, która kocham (nr 6/2012). Występujące na okładkach osoby symbolizują różne środowiska, przekraczając ikoniczny charakter znaku. Prowadząc swoją narrację, reprezentują nie tylko siebie, ale i określone grupy społeczne lub przynajmniej ich części (satyryków, artystów, ludzi władzy, przedstawicieli Kościoła).

Polska rzeczywistość i codzienność na okładkach „Uważam Rze” była prezentowana w sposób krytyczny bądź wskazywano na jej komiczny charakter. Do tego typu symboliki odwołuje się okładka, na której widzimy słynnego słomianego misia z komedii Stanisława Barei (nr 30/2012). Tekst na okładce naprowadza patrzącą na nią osobę na właściwe odczytanie symboliki: Esej Rafata A. Ziemkiewicza. Ile wokót nas PRL, a ile nowego? I dlaczego tym wszystkim cwaniakom budujacym „na miarę możliwości” wciąz jest tak dobrze? I dziśżyjemy w „Misiu”! Miś jest w tym przypadku symbolem poprzedniej epoki, jej absurdów, a także uprzywilejowanych grup społecznych, nagradzanych w czasach przed transformacją. Inna okładka odwołuje się z kolei do wydarzeń związanych z tzw. aferą Amber Gold (nr 35/2012). Na okładce (rysunek) widzimy sznur ludzi, ustawionych jeden za drugim. Kolejka ta wije się, zdaje się nie mieć początku i końca. Bardzo ważne jest jednak to, że każda z osób stojących w niej trzyma rękę w kieszeni osoby ją poprzedzającej, ukazując ciąg niekończącego się łapownictwa i korupcji. Na to zresztą wskazuje tekst: Korupcja. Nepotyzm. Klientelizm. Wtadza pozbawiona kontroli degeneruje się btyskawicznie. Fajna Polska w stylu Amber Gold. W kolejce stoją więc zdegenerowani przedstawiciele władzy. Symbolizują oni zasady współcześnie rządzących, sprowadzone do stwierdzenia w stylu Amber Gold.
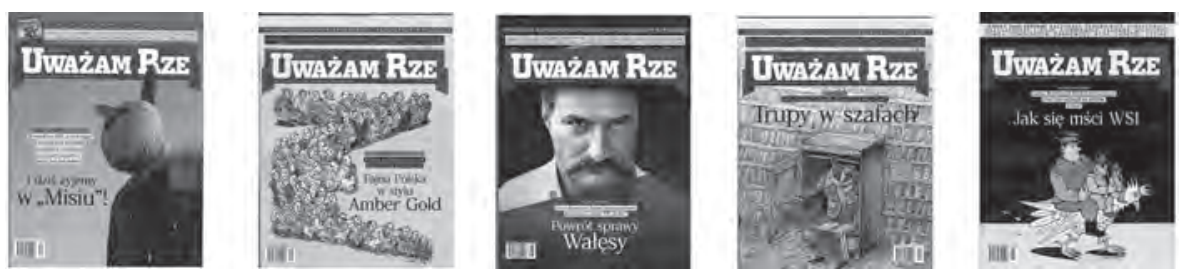

Ważne jest tu również sformułowanie fajna Polska. Sam termin nawiązuje do tytułu akcji zainicjowanej przez Tomasza Lisa (zaliczanego przez dziennikarzy „Uważam Rze” do tzw. Salonu). Było ono wielokrotnie wykpiwane i stało się tego samego rodzaju symbolem, co „lemingi” (o których będzie mowa w dalszej części), używanym do opisu grup i polityków akceptujących tzw. „politykę ciepłej wody w kranie” i koncentrację na konsumpcji.

$\mathrm{Na}$ okładkach pojawiają się również tematy związane z kulisami polityki czy politycznymi mechanizmami konkurowania aktorów politycznych i instytucji formalnych działających w ramach systemu politycznego. Widzimy więc np. zdjęcie twarzy gen. Sławomira Petelickiego wyłaniające się z ciemnego tła z podpisem: Zagadka śmierci gen. Petelickiego (nr 26/2012) albo rysunek przedstawiający żołnierski mundur wy- 
chodzący z szafy (nawiązanie do „trupów w szafach”) (nr 29/2012). Jedna z okładek, odnosząca się do postrzelenia się przez płk. Mikołaja Przybyła (nr 3/2012), wskazuje na prezydenta Bronisława Komorowskiego jako chroniącego układ w Prokuraturze Wojskowej. „Uważam Rze” umieszcza też na okładce zdjęcie Lecha Wałęsy (z czasów działalności opozycyjnej: jest ubrany w białą koszulę, patrzy przed siebie). Były prezydent nie pojawia się tam jednak w roli pozytywnej, a świadczy o tym umieszczony na okładce tekst: Nasze śledztwo. Czy w Kancelarii Sejmu ukryto zaginione dokumenty z teczki TW „Bolka”. Powrót sprawy Watęsy (nr 8/2012).

Najbardziej wymowna jest jednak okładka z rysunkiem orła białego w koronie, na którego „grzbiecie” siedzą trzej mężczyźni (nr 2/2012). Dwóch z nich nosi charakterystyczny strój tajniaka (płaszcz, kapelusz, przyciemniane okulary), zaś trzeci (największy z nich) ma na sobie mundur. Orzeł ugina się pod ciężarem mężczyzn, ma opuszczoną głowę, jest smutny. Symbolizuje tu udręczoną Polskę, zaś trójka mężczyzn to dobrze mające się tajne służby, z wyjątkową pozycją służb informacyjnych (orzeł i agenci jako znaki metonimiczne). Odbiorca zostaje też naprowadzony na właściwy sposób odczytania okładki przez zakotwiczenie: Stużby specjalne. Ludzie Wojskowych Stużb Informacyjnych przez lata wptywali na politykę. A dziśs? Jak się mści WSI.

Akcentowane są w ten sposób niewyjaśnione sprawy, zagadki, tajemnice, zakulisowa walka o wpływy, działania tajnych służb. Podmiotowość i obywatelskość polskiego społeczeństwa pozostają zatem wciąż niespełnioną obietnicą. Państwo i jego instytucje są słabe (poza służbami specjalnymi), a stojący na jego czele (obecnie i w przeszłości) urzędnicy stracili swój mandat do przewodzenia wspólnocie, nie pokazują prawdziwej twarzy, kłamią.

Trzy okładki „Uważam Rze” w badanym okresie odwoływały się do katastrofy smoleńskiej. Recenzowanie działań rządu w sprawie tego tragicznego wydarzenia stało się dla tygodnika pretekstem do oceny funkcjonowania państwa. Na jednej umieszczono czarno-białe zdjęcie metalowych przedmiotów dużych rozmiarów leżących w lesie (nr 4/2012). Oglądający powinien domyśleć się, że chodzi o szczątki Tupolewa i katastrofę smoleńską (sugeruje to zarówno tekst na okładce, jak i sama symbolika zdjęcia). $\mathrm{Na}$ jeden $\mathrm{z}$ fragmentów samolotu naniesiono (fotomontaż) biało-czerwoną szachownicę lotniczą, z której spływa czerwona kropla. Przywodzi ona na myśl kroplę krwi. Dramaturgia zdjęcia podsycana jest przez zestawienie czarno-białej fotografii z kolorową grafiką w narodowych barwach. Ważne jest również zakotwiczenie: Tragedia 10 kwietnia. Rosyjska, powielana w Polsce, wersja katastrofy rozsypata sie jak domek $z$ kart. Ktamstwo smoleńskie pęka.
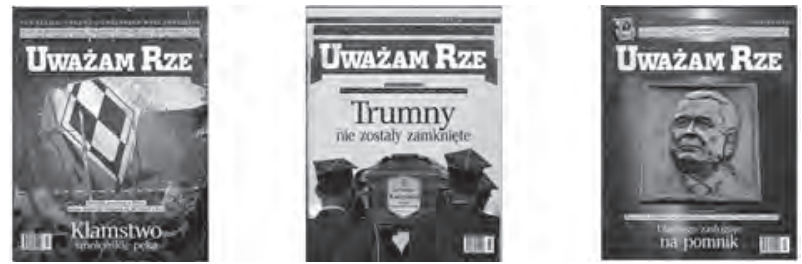
Obraz ten staje się symbolem - znakiem konotatywnym, zawierającym w sobie całą sumę znaczeń. Szczątki samolotu i „krwawiące” narodowe barwy mogą symbolizować trwałą ranę na narodzie, ranę, która się nie goi, gdyż przeszkadza temu ktamstwo smoleńskie. Inne okładki odnoszące się do Smoleńska przywołują postać zmarłego prezydenta Lecha Kaczyńskiego (raz jest to zdjęcie jego trumny niesionej przez żołnierzy, a raz - zdjęcie tablicy z jego popiersiem). To istotne, bowiem postać prezydenta staje się symboliczna dla środowiska „Uważam Rze” i jego czytelników. Jest on określany jako nasz wielki prezydent, któremu należy się cześć i rekompensata za niesprawiedliwe traktowanie przed śmiercią.

Narracja na temat tragedii smoleńskiej staje się więc metakodem; symbolika pozwala na tworzenie dychotomicznych podziałów prawda-fałsz, wielki-mały, nasz-wasz. Ponadto używane w tym przypadku instrumentarium symboliczne ma charakter metaznaków pozwalających na podkreślanie swej odrębności i przynależności do określonej grupy społecznej (np. wśród ludzi będących po stronie prawdy smoleńskiej czy oddających częśc Lechowi Kaczyńskiemu).

Polityka zagraniczna i problematyka relacji z unijnymi partnerami pojawia się na okładkach trzykrotnie. Tu z kolei mamy odwołanie to toposu „silnych i wielkich Niemiec". Na okładce zamieszczono zdjęcie kanclerz Angeli Merkel z podpisem Kanclerz Europy (nr 38/2012) oraz rysunek przedstawiający dłoń z nadgarstkiem pomalowanym w niemiecką flagę i palcem z skierowanym ku górze, którą otaczają mniejsze dłonie składające jej pokłon (Niemcy rządza) (nr 5/2012). Trzecia okładka związana z zagraniczną tematyką jest satyrą na Unię Europejską (nr 22/2012). W rydwanie zaprzęgniętym w grupę ludzi stoi kobieta i dwóch mężczyzn. Jeden z nich trzyma kij, na którego końcu wisi marchew ze znakiem euro, stanowiąca zachętę dla zaprzęgu. Trudno stwierdzić, kim są stojący w rydwanie mężczyźni, ale kobietą bez wątpienia jest Angela Merkel. Wymowa okładki jest jednoznacznie negatywna, wzmocniona tekstem-zakotwiczeniem: Unia Europejska. Coraz mniej zrozumiata, coraz bardziejpozbawiona demokratycznej kontroli. Dokąd nas wiodą eurozjady. W ten sposób zaakcentowano rolę Niemiec jako głównego aktora w Europie, zaś sama Unia staje się stowarzyszeniem dla wybranych, silnych państw potrafiących sterować innymi.
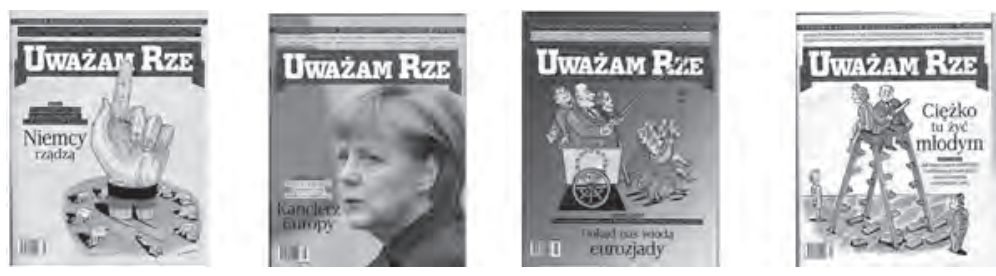

Tygodnik rzadko odwołuje się na swych okładkach do tematów społecznych. Właściwie tylko jedna okładka wprost odnosi się do próby diagnozy i opisu tego rodzaju problemów: chodzi o ocenę społecznego położenia ludzi młodych (nr 13/2012). Charakterystyka ta jest jednoznacznie negatywna, a symbolizuje ją na okładce drabina z przepiłowanymi szczeblami, na szczycie której siedzi para dorosłych ludzi, kobieta 
i mężczyzna, trzymających w rękach piły do drewna. Dwie młodsze osoby stojące na dole mogą jedynie spoglądać na tych na górze. Wątpliwości nie pozostawia również zakotwiczenie: Ciężko tu żyć mtodym. Jak chory system edukacyjny i zablokowany rynek pracy niszcza marzenia o normalnym życiu.

Tylko raz natomiast tygodnik odniósł się do turnieju Euro 2012 (nr 25/2012). Na okładce widzimy kibickę polskiej reprezentacji (znak ikoniczny). Sam znak nie naprowadza jednak oglądającego zdjęcie na właściwe jego odczytanie; robi to zakotwiczenie tekstowe: Euro 2012. Jak propaganda Platformy chce zawtaszczyć to, co należy do nas wszystkich. Święto Polaków, a nie wtadzy! Turniej staje się więc kolejną okazją do krytycznej oceny ugrupowania rządzącego i budowania dychotomii oni-rządzący i my-rządzeni.

\section{2. „Polityka”}

„Polityka”, opisując sposób funkcjonowania państwa i sceny politycznej, również skupia się na konkretnych postaciach (premier, członkowie rządu, znane postaci). Towarzyszący temu komentarz jest inny niż w przypadku „Uważam Rze”. Interesujący jest sposób prezentacji Donalda Tuska. W badanym okresie tylko raz trafia on na okładkę, w dodatku na zdjęciu jest odwrócony tyłem, co jednak nie przeszkadza w rozpoznaniu jego sylwetki (nr 7/2012). Tu również premier jest reprezentantem swojego gabinetu. To, dlaczego zaprezentowano go tyłem, wyjaśnia zakotwiczenie: Jak nie to nie. Rząd podejmuje reformy, ale sięprzy nich nie upiera. Okładka wraz z zakotwiczeniem staje się w całości znakiem konotatywnym odnoszącym się do modelu polityki „tu i teraz”.
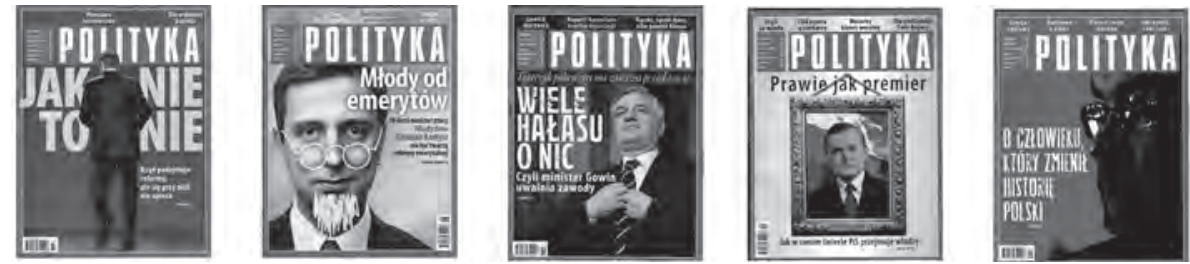

Może ona być również odczytana jako metakod, czyli kod dominujący związany w tym przypadku ze stylem rządzenia, uprawiania polityki i rozumieniem relacji rządzący-rządzeni, mającej charakter transakcyjny, opierający się na swoistym kontrakcie między liderem a zwolennikami ${ }^{14}$. Kluczowe dla rządzących jest jednak utrzymanie się przy władzy. Stąd uwaga wskazująca na łatwą rezygnację premiera z forsowania reform.

$\mathrm{Na}$ innych okładkach nawiązujących do funkcjonowania państwa i inicjatyw politycznych obozu rządzącego prezentowani są wybrani ministrowie, jako twarze swoich resortów i przygotowywanych w nich rozwiązań i projektów (np. zdjęcie ministra

14 J. M. Burns, Wtadza przywódcza, [w:] Wtadza i spoteczeństwo. Antologia tekstów z zakresu socjologii polityki, t. 1, wybór i oprac. J. Szczupaczyński, Warszawa 1995, s. 261-273. 
Władysława Kosiniaka-Kamysza z dorysowaną brodą i podpisem: Mtody od emerytów; nr 8/2012). Redakcja jest jednak sceptyczna co do powodzenia i procesu wdrażania postulowanych zmian. Dobrze oddaje to zakotwiczenie w postaci tekstu na okładce z Jarosławem Gowinem (nr 11/2012): Teatrzyk polityczny ma zaszczyt przedstawić. Wiele hatasu o nic. Czyli minister Gowin uwalnia zawody. Zwraca uwagę forma teatrzyk. Użycie zdrobnienia jest tu zabiegiem celowym, mającym podkreślić krytyczną wymowę tego stwierdzenia. Zdążyliśmy się przyzwyczaić do metafory teatru i sceniczności zachowań aktorów politycznych, jednak podejmowane przez ministra sprawiedliwości działania zdaniem redakcji nie mogą być określane jako teatr, lecz jako teatrzyk właśnie.

$\mathrm{Na}$ okładce tygodnika pojawia się również opozycyjny kandydat na premiera (nr 40/2012). W centralnej jej części widzimy zdjęcie Piotra Glińskiego (tzw. popiersie). Jest to zdjęcie pozowane, na którym Gliński delikatnie się uśmiecha. Widzimy, że ma na sobie białą koszulę, bordowy krawat w delikatny wzór oraz czarną marynarkę. Tło za sfotografowaną postacią wypełnia biało-czerwona flaga i kolor niebieski. Takie zdjęcie mogłoby być oficjalną fotografią prezesa rady ministrów. Ważna jednak jest w tym przypadku obróbka zdjęcia. Zostało ono wpisane w bogatą, złotą ramę, stając się tym samym obrazem zawieszonym na haczyku wbitym w białą ścianę. Nad obrazem umieszczono tekst (zakotwiczenie): Prawie jak premier. W tym przypadku relacja między znaczącym (Piotr Gliński na tle polskiej flagi) a znaczonym (osoba ważna, premier, mąż stanu, instytucje rządowe) ma charakter skonwencjonalizowany. Istotny jest jednak przede wszystkim symboliczny zabieg prezentacji zdjęcia jako obrazu oraz dokonane zakotwiczenie. Wpływają one bowiem na reżim odbioru. Okładka staje się tutaj znakiem konotatywnym; prezentowana na niej osoba jedynie udaje premiera, jego kandydatura staje się sztuczną propozycją, tak jak dokonany zabieg obróbki zdjęcia. Bardzo istotne są w tym przypadku słowa: prawie jak..., które od czasu kampanii reklamowej jednego z producentów piwa stały się używanym powszechnie terminem wskazującym na znaczącą różnicą między oryginałem a tym, co próbuje nim być (co go udaje). Taka forma symboliki jest adresowana do grupy społecznej (czytelników „Polityki”), która będzie w stanie właściwie ją odczytać; zrozumie żart redakcji, skonfrontuje go ze swoim systemem odniesień i poprawnie odkoduje. Zrozumie, że kandydatura Glińskiego na premiera to element politycznej gry, jaką Prawo i Sprawiedliwość prowadzi w swoim świecie (tekst na dole okładki brzmi: Jak w swoim świecie PiS przejmuje wtadze). Możemy zatem w tym przypadku mówić również o określonej prezentacji podziałów socjopolitycznych, a tym samym próbie scalania wiedzy na linii redakcja-czytelnicy, czyli występowania semantycznej koherencji między ich opisami świata ${ }^{15}$.

Dodać w tym miejscu należy, że na okładkach „Polityki” w badanym okresie właściwie nie odnoszono się do ugrupowań opozycyjnych czy reprezentujących je polityków. Chyba że uznać za takie opisywaną wyżej okładkę z Piotrem Glińskim oraz tę z Włodzimierzem Czarzastym (czarno-czerwona okładka, zdjęcie twarzy z profilu, twarz słabo oświetlona, trudno rozpoznać, kto to jest) z tekstem: O cztowieku, który

15 T. A. van Dijk, Badania nad dyskursem, [w:] Dyskurs jako struktura i proces, red. tenże, wybór i przeł.

G. Grochowski, red. nauk. T. Dobrzyńska, Warszawa 2001, s. 9-44. 
zmienit historię Polski. Ten drugi przypadek w większym stopniu niż opozycyjnego SLD dotyczy tzw. afery Rywina (nr 21/2012).

Wśród okładek „Polityki” w badanym okresie przeważają odnoszące się do identyfikacji i diagnozy problemów oraz zjawisk społecznych. Nie daje to, ze względu na określony zakres badania, możliwości orzekania na temat pewnych trwałych tendencji. Ograniczając jednak wnioskowanie do przebadanego korpusu, można stwierdzić, że „Polityka” na swych okładkach prezentowała się jako tygodnik akcentujący ważne (w przekonaniu redakcji) problemy społeczne, zmierzając w kierunku social magazine. Rzadziej w ten sposób komponuje okładki „Uważam Rze”, którego redakcja daje pierwszeństwo treściom stricte związanym z polityką (szczególnie zaś z jej ujęciem jako politics). Polityka demograficzna, konflikty pokoleniowe, zdrowie publiczne, czyli problematyka podejmowana na okładkach, wiążą się z postrzeganiem polityki jako narzędzia rozwiązywania społecznych wyzwań. Tego typu komunikaty odbiegają bowiem od prezentowania polityki wyłącznie w formule rywalizacyjno-oskarżycielskiej.
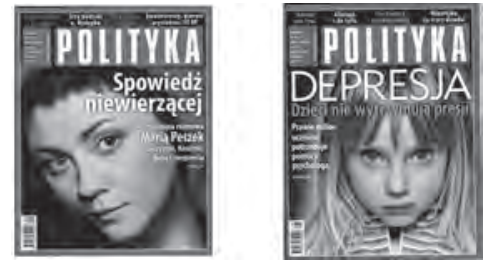

Prezentowanie istotnych problemów społecznych na okładkach „Polityki” dokonywane jest zwykle przez prezentację wizerunku konkretnej postaci. Mogą to być osoby znane i/lub reprezentujące określoną grupę społeczną. Wizerunki te można traktować jako znaki ikoniczne. Maria Peszek na okładce jest Marią Peszek (nr 39/2012). Artystka jest jednocześnie przedstawiona jako niewierząca i zmagająca się z depresją. Zakotwiczenie w tym przypadku brzmi: Spowiedź niewierzacej. Wstrząsająca rozmowa z Mariq Peszek o Ojczyźnie, Kościele, Bogu i cierpieniu. W ten sposób wizerunek artystki staje się znakiem syndekdochalnym - reprezentuje ona większą grupę osób zmagających się z depresją i przeżywających rozterki związane ze swoim życiem zawodowym, rodzinnym i religijnym (fakt, że jest osobą znaną, wzmacnia ten swoisty coming out). Zastanawia natomiast użycie przez tygodnik w zapowiedzi wywiadu słowa wstrzasajaca, zwykle charakterystycznego nie dla tzw. quality press, ale dla tabloidów.

Do podobnego problemu nawiązuje okładka, na której widzimy zbliżenie twarzy dziecka (prawdopodobnie dziewczynki, znak paradygmatyczny: dziecko - nie dorosły) patrzącego wprost w obiektyw; ma ono smutny wyraz twarzy (nr 38/2012). Tygodnik zajmuje się w tym numerze problemem depresji wśród dzieci. Tekst na okładce ma charakter alarmujący: Depresja. Dzieci nie wytrzymuja presji. Prawie milion uczniów potrzebuje pomocy psychologa. Oprócz diagnozy samego problemu pojawia się tu również odwołanie do wzrastającej presji kulturowej na właściwą realizację planu biograficznego, który zaczyna dotyczyć również najmłodszych. 
W związku z tym, że w okresie zbierania materiału badawczego odbywały się Igrzyska Olimpijskie w Londynie, trzy okładki nawiązywały do tego wydarzenia (wydarzenie to nie pojawia się na okładkach „Uważam Rze”). Nie koncentrowały się one jednak wprost na kwestiach dotyczących rywalizacji sportowej, lecz odnosity się do problemów związanych z uprawianiem sportu zawodowego: budowania kariery sportowca i drogi na szczyt. Taki charakter miały okładki ze zdjęciami Jadwigi Jędrzejowskiej i Agnieszki Radwańskiej - finalistek Wimbledonu (nr 28/2012) oraz Karoliny Michalczuk, jedynej polskiej bokserki w Londynie (nr 29/2012). W przypadku tenisistek zakotwiczenie brzmiało: Kariery niemożliwe, zaś w przypadku bokserki: Honoru polskiego boksu będzie bronić samotnie kobieta. Olimpijka. Niezwykta historia Karoliny Michalczuk. Przedstawione na okładkach wizerunki sportsmenek można odczytać jako znaki ikoniczne, ale symbolizują one również indywidualizm i częstą konieczność samodzielnego planowania i kształtowania swojej kariery, bez pomocy środowiska instytucjonalnego, w tym państwa.
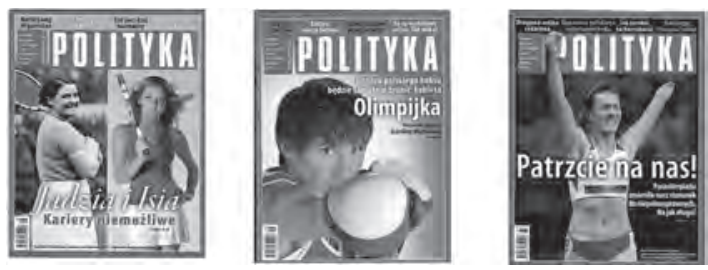

Okładką odnoszącą się do tematyki sportowej, która w tym przypadku jest jedynie pretekstem do analizy innego problemu, jest ta przedstawiająca niepełnosprawną lekkoatletkę (nr 37/2012). Widzimy na niej Alicję Fiodorow, reprezentantkę Polski w biegach na 200 i 400 metrów na Paraolimpiadzie w Londynie. Została ona sfotografowana w reprezentacyjnym stroju biegaczki, w momencie kiedy prawdopodobnie mija linię mety, gdyż ma ręce uniesione do góry w geście zwycięstwa. Uwagę zwraca fakt, że biegaczka nie ma lewego przedramienia. Na okładce widnieje tekst: Patrzcie na nas! Paraolimpiada zmienita nasz stosunek do niepetnosprawnych. Na jak dtugo? Tym razem więc gazeta wprowadza do agendy publicznej problem niepełnosprawności i stosunku społeczeństwa do osób niepełnosprawnych.
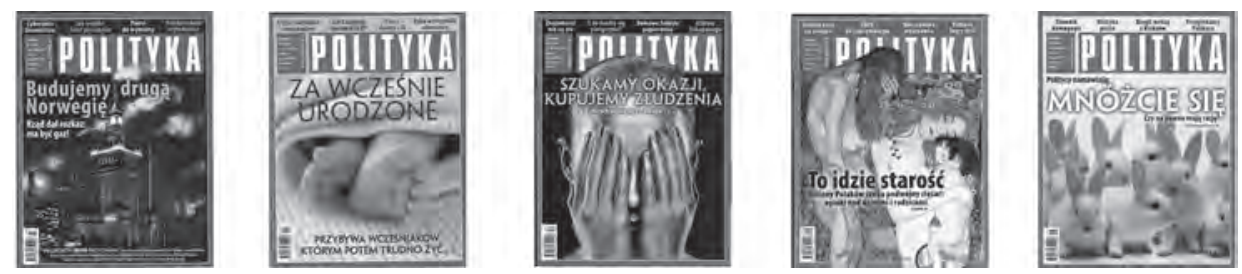

Wiele okładek „Polityki” stanowi komentarz do bieżącej polityki rządu i wydarzeń w kraju. Ich wybór wpisuje się w procedurę ustalania agendy medialnej, co przekłada się na repertuar problemów wymagających uwagi społeczeństwa, a przynajmniej czytelników tygodnika. Katalog analizowanych kwestii jest spory. Są to sprawy dotyczące roz- 
wiązań systemowych, np. polityki zdrowotnej państwa, problemów demograficznych czy wydobywania gazu łupkowego. Okładki są również miejscem komentowania bieżących wydarzeń z ich odniesieniem do makroskali. Dotyczy to m.in. sytuacji w wojsku (w związku z samookaleczeniem płk. Przybyła), pytań o infrastrukturę kolejową (po katastrofie w Szczekocinach), problemu edukacji ekonomicznej Polaków i ich strategii inwestycyjnych (punktem wyjścia rozważań jest tzw. afera Amber Gold), sfery seksualnego życia Polaków (odniesienie do raportu prof. Zbigniewa Izdebskiego poświęconego tym zagadnieniom). Okładki ta mają neutralny charakter. Trudno uznać, aby prezentowane tam znaki wiązały się z ich negatywnym odczytaniem. Często są to znaki metonimiczne - np. gdy mowa o polityce demograficznej i zachęcaniu Polaków do posiadania dzieci, na jednej okładce umieszczono stopy dziecka (dziecko-przyszłość), na drugiej zaś króliki (królik-rozmnażanie). Bardziej symboliczne są okładki odwołujące się do wspomnianych wyżej problemów z wydobywaniem gazu lupkowego i sytuacji w wojsku. $\mathrm{Na}$ jednej z nich widzimy bowiem fotomontaż przedstawiający zdjęcie Pałacu Kultury i Nauki, którego iglica zamieniona została w komin z wydobywającym się zeń płomieniem (charakterystycznym dla odwiertów gazowych); podobne cztery kominy stoją w jego otoczeniu (nr 3/2012). Na okładce widnieje tekst: Budujemy druga Norwegię. Rząd dat rozkaz: ma być gaz! Użycie takiego właśnie zakotwiczenia ma pozwolić oglądającemu na właściwe odkodowanie przekazu. W tym przypadku chodzi o zachowanie dystansu, zwłaszcza w zakresie aspiracji do stania się mocarstwem gazowym i możliwości sprawczych rządu w tym zakresie. Zwraca również uwagę to, że na okładkach rzadko za istniejący stan rzeczy (problemy ze wskaźnikami demograficznymi, pojawiający się oszuści finansowi) obwinia się rządzących czy konkretne ugrupowanie. Redakcja z reguły przedstawia określony problem, nie starając się narzucać interpretacji. Tak jak na okładce odnoszącej się do tzw. afery Amber Gold (nr 34/2012), gdzie nie ma mowy wprost o tym wydarzeniu czy o głównych aktorach tego spektaklu. Wskazuje się za to na problem dotyczący ogółu, mający swe źródło w konsumpcyjnych i materialnych podstawach dzisiejszych treści kulturowych. Identyfikowane na okładkach problemy społeczne są z reguły prezentowane jako korespondujące bądź będące wynikiem zmian cywilizacyjnych, przekształceń w ramach skal aksjonormatywnych, procesów rynkowych. Niekiedy po prostu wskazuje się na kierunek zmian społecznych, orzekając poniekąd o ich nieuchronności. Tak jest w przypadku okładki dotyczącej starzenia się społeczeństwa i wyzwań czekających Polaków w średnim wieku co do opieki nad dziećmi i rodzicami. Jako ilustrację tego zjawiska wybrano obraz Gustava Klimta Trzy okresy życia kobiety (nr 35/2012).

Wielokrotnie okładki „Polityki” dotyczyły turnieju Euro 2012. Nie odnosiły się jednak wprost do gry naszej reprezentacji i wyników uzyskanych na turnieju, ale poruszały problemy związane z tą imprezą. Wskazywano na dużą popularność wolontariatu w służbach organizacyjnych mistrzostw - na okładce widzimy zdjęcie dwójki młodych, uśmiechniętych ludzi, wolontariuszy, na ekranie smartfona (nr 25/2012). Na innej z kolei stadion w Gdańsku (jedna z aren Euro) odlatuje w górę niczym statek kosmiczny. Redakcja pyta zaś: Odlot czerwcowy. Co w nas zostanie po Euro? (nr 26/2012). $\mathrm{Na}$ innych związanych z tym tematem okładkach zapowiedzi dotyczą głównie kwestii 
organizacyjnych, stanu naszego przygotowania i tego, co będzie działo się po turnieju. Ta ostatnia kwestia stała się zresztą pretekstem do długiego wywiadu z premierem Donaldem Tuskiem, zapowiadanego na okładce popularnym internetowym memem, przedstawiającym robotników zwijających asfalt na autostradzie, jakby zwijali trawnik rozwinięty z rolki. Całość uzupełnia tekst: Jak żyćpo Euro? Donalda Tuska pytamy o jego kadre i plan gry. Mamy więc nawiązanie do pytania: Jak żyć? Zadał je premierowi plantator papryki Stanisław Kowalczyk, który wziął udział w kampanii PiS. Tekst odnosi się też do pasji premiera - piłki nożnej.

Na okładkach „Polityki” w badanym okresie właściwie nie pojawia się problematyka związana z polityką zagraniczną i relacjami zewnętrznymi Polski. Jedna z okładek ze zdjęciem Cyryla I, patriarchy Moskwy i Wszechrusi, nawiązywała do relacji polsko-rosyjskich oraz stosunku między kościołem katolickim i prawosławnym (zakotwiczenie: Misja Cyryla, nr 32-33/2012).

Zestawiając ze sobą dwie narracje prowadzone na okładkach tych tygodników, można stwierdzić, że „Polityka” częściej odwołuje się do przywództwa transakcyjnego, opierającego się na kontrakcie między wyborcami a powiernikiem ich oczekiwań, w tym przypadku określonym politykiem (członkiem rządu, posłem). W „Uważam Rze” częściej natomiast widać tęsknotę za przywództwem transformacyjnym, w którym lidera i zwolenników łączy więź emocjonalna i chęć dokonywania zmian w imieniu i interesie całej wspólnoty (np. narodu).

\section{NOWE PODZIAŁY SOCJOPOLITYCZNE, TOŻSAMOŚCIOWE I AKSJOLOGICZNE WE WSPÓŁCZESNYM POLSKIM SPOŁECZEŃSTWIE}

\section{1. „Uważam Rze”}

Jednym z najlepszych przykładów prezentacji nowych podziałów socjopolitycznych jest okładka, na której zamieszczono rysunek przedstawiający dwie lalki, kobietę i mężczyznę, siedzące w samochodzie (nr 28/2012). Postaci te znajdują się na pierwszym planie, a wzrok kobiety jest skierowany na patrzącego na okładkę. Tło w tym przypadku jest nieistotne (prawdopodobnie widać na nim niebieskie niebo i zielone rośliny). Lalki przypominają zabawki znane pod imionami Barbie i Ken. Obie postaci są uśmiechnięte, ich wygląd jest atrakcyjny, nie mają właściwie żadnych defektów estetycznych i z dumą prezentują śnieżnobiałe uzębienie. Kobieta ma na lewym ramieniu naklejony plaster antykoncepcyjny. W ręce trzyma smartfon z logo, które bardzo przypomina „jabłko” firmy Apple. Siedzący obok mężczyzna ma okulary przeciwsłoneczne przypominające wzorem kultową markę Ray-Ban, jest ubrany w różową koszulkę z postawionym kołnierzykiem, której logo łudząco przypomina markę Ralph Lauren, w ręce zaś trzyma kubek z charakterystycznym zielonym motywem nawiązującym do marki Starbucks. Ważne jest również to, że samochód prowadzi kobieta, a nie mężczyzna. Widzimy więc wystylizowaną parę, prezentującą swą pozycję społeczną przy pomo- 
cy określonego typu gadżetów (co nawiązuje do zjawiska symbolizmu statusu ${ }^{16}$ ). Taka symbolika ma pozwolić oglądającemu na zaliczenie tych postaci do określonej grupy społecznej. Bardzo ważne jest również zakotwiczenie, czyli tekst: Lemingi nad Wistą. To nawiązanie do określenia lemingi, stosowanego przez niektórych publicystów do opisu grupy społecznej skoncentrowanej na nieskrępowanej konsumpcji, niezainteresowanej polityką, dla której liczy się „łatwe życie” i zaspokajanie swych potrzeb. Tego rodzaju symbolika nie musi być czytelna dla wszystkich. Wydawca zakłada jednak (decydując się na taką okładkę), że będzie ona zrozumiała dla tych, którzy - będąc czytelnikami „Uważam Rze” - uczestniczą wraz z tym tytułem w procesie scalania wiedzy. Dla jednej i drugiej strony ten obraz i obecne na nim znaki (wzmocnione dodatkowo zakotwiczeniem) przyjmują określone znacznie. Obecna na okładce para może być traktowana jako znak syndekdochalny reprezentujący całą grupę społeczną, którą można „roboczo” określić jako Młodych Wykształconych z Wielkich Miast.
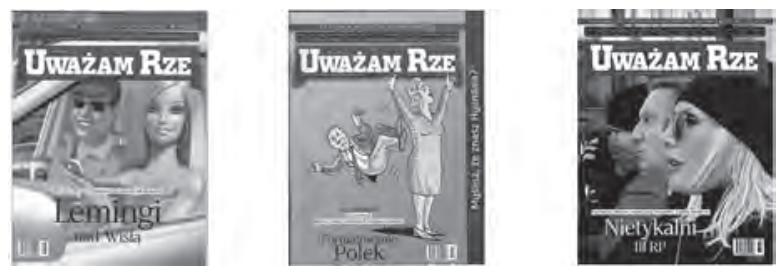

Para ta, a zarazem cała grupa, jest przedstawiona jako sztuczna, otoczona modnymi gadżetami i zorientowana na konsumpcję (w ten sposób lalki wraz z posiadanymi przez nie przedmiotami stają się znakami konotatywnymi, nośnikami szerszej gamy znaczeń). Tego rodzaju symbolika ma umożliwić odbiorcy (uczestniczącemu w procesie scalania wiedzy) prawidłowe odczytanie przekazu. Dodatkowo powinien się on odnosić do kodów i systemów odniesień pomocnych w jego zrozumieniu. Odkodowanie okładki może więc wpisywać się w system zestawień binarnych: świat ludzi sztucznych (somnambulicznych lemingów) i świat ludzi prawdziwych, ludzie koncentrujący się pozorach (symbolizowanie swojego statusu przez nieskrępowaną konsumpcję) i ludzie koncentrujący się na "prawdziwym życiu”, lemingi i mohery. W ten sposób dochodzi do wytworzenia określonego reżimu skopicznego, a tym samym reżimów wytwarzania i odbioru.

Podłożem dla wykształcania się tego rodzaju podziałów mogą być podziały kulturowe, dotyczące między innymi takiej zmiennej, jak styl życia. Dotyczy tego również okładka odnosząca się do nowych ról społecznych kobiet. To rysunek przedstawiający kobietę w niebieskiej sukience i butach na niskim obcasie, która uśmiecha się i trzyma ręce uniesione w górę w geście zwycięstwa. Za nią widzimy ubranego w garnitur, upadającego (plecami w dół na ziemię) mężczyznę. Zakotwiczenie brzmi: Feministki $w$ akcji. Cel operacji: odarta $z$ więzi rodzinnych wieczna singielka. Formatowanie Polek (nr 10/2012). Taka prezentacja i komentarz są ostrzeżeniem przed działaniami (w tym przypadku feministek) kwestionującymi tradycyjne scenariusze ról społecznych.

16 P. Berger, Zaproszenie do socjologii, przeł. J. Stawiński, Warszawa 1995, s. 80. 
W podziały wpisuje się też okładka, na której widzimy fotomontaż zestawiający profile trzech osób. Układ ten nie jest przypadkowy; przywodzi na myśl zestawianie na plakatach propagandowych i sztandarach wizerunków Marksa, Engelsa i Lenina. Profile na okładce należą do Kory Jackowskiej, Krzysztofa Piesiewicza i nieznanej osoby (prawdopodobnie mężczyzny), której strój (kolor czarny) i zamaskowana twarz czynią z niej reprezentanta ruchu anarchistycznego bądź antyglobalistycznego. Każda z prezentowanych postaci może być traktowana jako znak syndekdochalny reprezentujący określoną grupę (większą całość), zbiorczo zaś te trzy osoby mają symbolizować III RP. Na to bowiem uwagę odbiorcy kieruje zakotwiczenie: Prawo i życie. Sa ludzie, którym wolno dziś wszystko. Sa bezkarni. Nietykalni III RP (nr 26/2012). Przekaz na okładce najszybciej odkodują we właściwy sposób osoby, które interesują się bieżącymi wydarzeniami. Chodzi bowiem o nawiązanie do niedawnych sytuacji, kiedy każda z tych osób weszła w konflikt z prawem. Jednak i odbiorcy, którzy nie znają dokładnie losów prezentowanych postaci, będą w stanie poprawnie odczytać przekaz dzięki zakotwiczeniu. Znaczące (czyli w tym przypadku wizerunki postaci na okładkach) odnoszą się bowiem do podziałów społecznych: przegrani-wygrani czy nowocześni-tradycyjni, pełniąc tym samym funkcję metakodów.
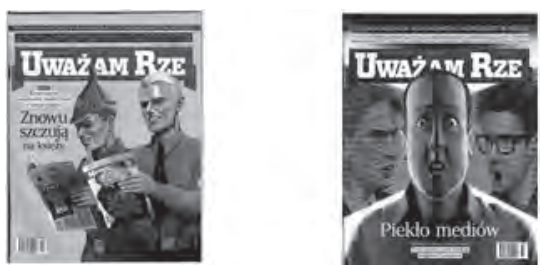

Charakterystyczna jest również krytyka stanu współczesnych mediów obecna w wyrazistej symbolice na okładkach „Uważam Rze”. Przede wszystkim, jak zazwyczaj w przypadku tego tygodnika, rzeczywistość charakteryzowana jest jako nasycona konfliktem, często o charakterze dychotomicznym (My-Oni). Jedna z okładek wskazuje na ataki części mediów na instytucję Kościoła i jego kapłanów. Symbolika jest niezwykle ostra. Na okładce (rysunek) widzimy dwóch mężczyzn: jeden w stroju czekisty czyta tygodnik „Nie”, drugi w stroju enesdeapowca czyta „Newsweek”. To reakcja „Uważam Rze” na artykuły krytykujące sytuację w Kościele, które pojawiły się w „napiętnowanych" tygodnikach. Warto też zwrócić uwagę na fakt, że okładka nadaje pejoratywne etykiety również czytelnikom tych gazet. Symboliczne zestawienie tygodników z systemami totalitarnymi nie pozostawia właściwie żadnego miejsca na spór czy polemikę. Podobnie w innym przypadku, gdzie symbolem medialnego piekta są na okładce Kuba Wojewódzki i Tomasz Lis (redaktor naczelny „Newsweeka”). Nie jest w tym przypadku istotne, że postaci te reprezentują różne formy i style dziennikarstwa. Istotne jest to, że są przedstawicielami drugiej strony sporu, często określanej na łamach „Uważam Rze” jako tzw. Salon. Należy założyć, że intencją nadawcy jest w tym przypadku samowykluczenie z piekta mediów i ustawienie się w pozycji cenzora; swoich czytelników uznają natomiast za, po pierwsze, atakowanych agresywnymi przekazami medialnymi konku- 
rencji, po drugie - sięgających po tygodnik wysokiej jakości (quality press), wolny od nachalnej agresji.

Wśród nowych podziałów socjopolitycznych znajduje się również stosunek do polskości, patriotyzmu czy dumy narodowej. Na okładkach „Uważam Rze” dostrzegalne są różne resentymenty, od toposu „Polski walczącej” po topos „Polski rycerskiej”. W niektórych przypadkach można wręcz mówić o syndromie „oblężonej twierdzy” - polskości jako czegoś, czego należy bronić przed zagrożeniami, zarówno zewnętrznymi, jak i wewnętrznymi. Na okładkach „Uważam Rze” naród jest przedstawiany jako najważniejsza i najwyższa forma wspólnoty. Takie jego postrzegane jest charakterystyczne dla doktryny konserwatywnej, która dla wielu autorów tygodnika stanowi punkt wyjścia do definiowania poglądów. W konserwatyzmie naród jako nosiciel tradycji i wspólnota organizująca życie jednostki zajmuje centralne miejsce w definiowaniu celów politycznych.
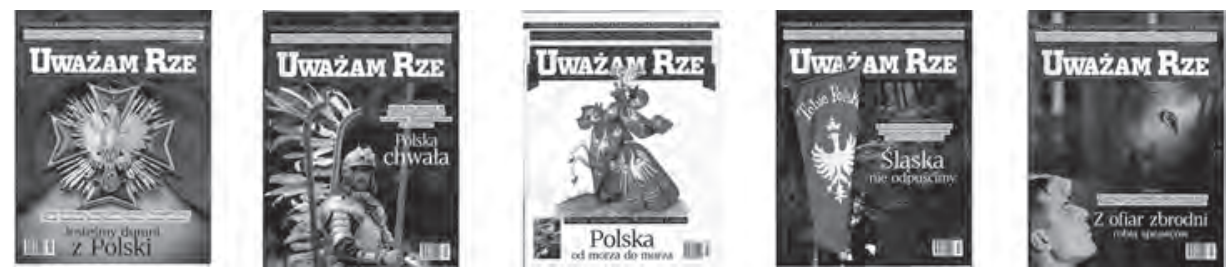

Na okładkach widzimy w zbliżeniu Order Orła Białego - najwyższe i najstarsze odznaczenie w Rzeczypospolitej Polskiej (nr 9/2012), mężczyznę w stroju rycerza husarii (prawdopodobnie zdjęcie przedstawia kogoś zajmującego się rekonstrukcją historyczną bądź jest kadrem z filmu historycznego) (nr 20/2012), polskiego króla (prawdopodobnie z dynastii Jagiellonów) na koniu (nr 27/2012). Stanowcze i emocjonalne są również zakotwiczenia tekstowe: Jesteśmy dumni z Polski, Polska chwata, Polska od morza do morza. W tych obrazach obecne są resentymenty i mity odnoszące się do polskiej mocarstwowości, siły militarnej, gotowości do poświęceń dla ojczyzny. Tygodnik bardzo wyraźnie wyraża opinię w dyskusji dotyczącej Śląska (nr 12/2012). Na okładce widzimy zdjęcie młodego mężczyzny (po raz kolejny może to być kadr filmu historycznego, rekonstrukcja historyczna dotycząca Powstań Śląskich czy też uroczystość upamiętniająca te wydarzenia), ubranego w charakterystyczny dla powstańców śląskich strój - ma na lewym przedramieniu białą opaskę, noszoną przez „zwykłych” żołnierzy-powstańców. Mężczyzna trzyma czerwony sztandar z białym orłem w koronie i napisem: Tobie Polsko (sztandar ten pojawiał się m.in. na manifestacjach na Śląsku, np. w 100. rocznicę uchwalenia Konstytucji 3 Maja). Tekst umieszczony na okładce brzmi: Stop fatszowania historii. Za gtośnym ruchem separatystycznym kryja się antypolskość, manipulacja i dążenie do rozbicia państwa. Ślaska nie odpuścimy. Polskość i integralność terytorialna oraz tożsamościowa ojczyzny są w opinii nadawcy komunikatu zagrożone. Redakcja wraz z czytelnikami stara się zidentyfikować problem i źródło zagrożenia oraz ogłasza swój sprzeciw. Warto również zauważyć, że pośrednio kwestia fatszowania historii pojawia się na jednej z okładek, gdzie zaprezentowano kadr z seria- 
lu Czas honoru (gestapowiec przesłuchuje żołnierza AK). W tym przypadku znaki na okładce są ikoniczne - gestapowiec i akowiec. Mają jednak one prowokować odbiorcę do refleksji (nr 24/2012). Służy temu (na co wielokrotnie zwracano uwagę w artykule) odpowiednie ukierunkowanie przekazu za pomocą tekstu. Brzmi on: Historia. Do czego prowadzi pedagogika wstydu stosowana wobec Polaków? W jaki sposób możemy się jej przeciwstawić? $Z$ ofiar zbrodni robia sprawców. Powraca więc kwestia relacji polsko-niemieckich, problem definiowania i odczytywania poszczególnych okresów naszej historii. Polskość (Polska) jest czymś zagrożonym, czego trzeba bronić, bądź przynajmniej dawać świadectwo, np. dumy przynależności do narodu. Oskarżycielsko brzmiąca pedagogika wstydu jest wyraźnie jednoznaczną i negatywną oceną, jaką redakcja wystawia innym środowiskom, które odczytują historię Polski nie tylko jako narrację o pokrzywdzonych, ale również jako opowieść o sprawcach i winnych krzywd innych. Treści te mogą być próbą nowego definiowania patriotyzmu i odrzucenia etykiety ksenofobii z jednej strony, z drugiej zaś - „polityki na kolanach” wobec historii własnej i sąsiadów (zwłaszcza jednego z nich - Niemiec).

Relacja między znaczącymi a znaczonymi ma w w tych przypadkach charakter symboliczny. Przedstawione na okładkach wizerunki (zdjęcia, rysunki, fotomontaże) mają symbolizować określone idee, charakterystyczne dla transformującego się społeczeństwa, zdaniem nadawców zmierzającego w stronę kultury wykluczenia, odejścia od tradycji. Analizując badany materiał, można dojść do wniosku, że na okładkach „Uważam Rze" podziały socjopolityczne nie są tylko odtwarzane i prezentowane, ale również tworzone i nazywane.

\section{2. „Polityka”}

Główna różnica w zakresie kategorii związanej z „nowymi podziałami socjopolitycznymi" między dwoma analizowanymi tygodnikami polega na tym, że w ramach korpusu badawczego poddawanego analizie do tego zbioru zaliczyć można zdecydowanie mniej okładek „Polityki”. Redakcja rzadko obsadza siebie w roli arbitra, a opisywane podziały nie mają „czarno-białego" charakteru.

Jedna z okładek nawiązuje do podziałów i rywalizacji na rynku medialnym, czego konsekwencją są podziały socjopolityczne, m.in. konsolidacja grup społecznych wokół wartości kojarzonych z określonym nadawcą. Na okładce, o której mowa, widać fotomontaż: głowę ojca Rydzyka wmontowano zamiast głowy pomnika (nr 16/2012). Rzeźba przypomina tę przedstawiającą anioła (Gabriela bądź Michała), stojącą na szczycie Zamku Anioła w Rzymie (pomnik ten prawdopodobnie symbolizował anioła chowającego zakrwawiony miecz do pochwy, co miało być wyrazem przebłagania Boga o zakończenie epidemii w Rzymie). Trudno zakładać, że czytelnicy „Polityki” dokładnie znają angelologię, ale symbolika w tym przypadku jest czytelna: dotyczy prezentacji ks. Rydzyka jako anioła walczącego i broniącego reprezentowanej przez siebie wspólnoty. Sam zabieg fotomontażu i modalność kompozycyjna okładki powodują, że przedstawiona postać (podobnie jak reprezentowane przez nią środowisko Radia Maryja i Telewizji Trwam) ma nieco komiczny charakter. Zakotwiczenie: Obrońca multipleksu 
ukierunkowuje uwagę oglądającego na kwestię szeroko rozumianych interesów wiążących się z rynkiem medialnym. W ten sposób kwestie religijne związane z wiarą mogą zejść na drugi plan, ustępując miejsca kwestiom ekonomicznym i politycznym.
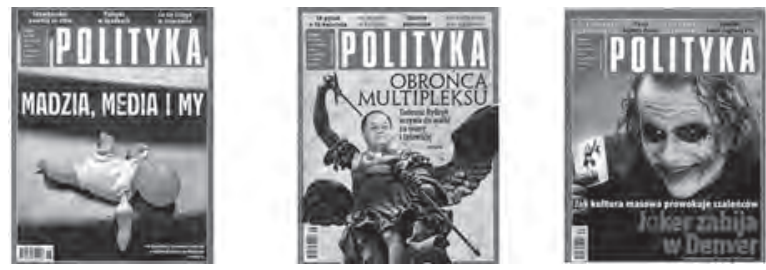

„Polityka” komentuje na swoich okładkach również działania współczesnych mediów i ich wpływ na kształtowanie się środowiska normatywnego w społeczeństwie. Pierwszy obraz, o którym mowa, jest przygnębiający. Na okładce widać zniszczoną lalkę (powyginane ręce i nogi) w przybrudzonym białym ubranku (nr 6/2012). Leży ona na schodach (została porzucona?). Zabawka może być tylko zabawką, jednak w tym przypadku jest znakiem symbolicznym. Obraz nawiązuje bowiem do wydarzenia, które relacjonowały właściwie wszystkie krajowe media - do tzw. sprawy Madzi z Sosnowca. Tekst na okładce brzmi: Madzia, media i my. Uwagę zwraca uwagę zaimek my. Można go odczytać w różny sposób: jako my - Polacy (społeczeństwo, widzowie, obserwatorzy), my - wspólnota: tygodnik, dziennikarze i jego czytelnicy. Lalka na okładce kojarzy się z dzieckiem (znak indeksowy), w tym przypadku nieżyjącym, którego tragedią polskie media żyły (a dla niektórych żywiły się) przez wiele tygodni. Zestawienie tego obrazu z tekstowym zakotwiczeniem kieruje dodatkowo uwage odbiorcy na to, w jaki sposób media relacjonowały te wydarzenia, jak zachowywała się publiczność i co można na tej podstawie powiedzieć o współczesnym społeczeństwie i samych mediach.

Do podobnego problemu nawiązuje okładka, na której widać filmowy kadr z Mrocznego Rycerza. Przedstawia on Jokera (granego przez Heatha Ledgera) - czarny charakter z trylogii Batman. Może on być postrzegany jako ikona (postać Jokera, znany aktor, który umiera w młodym wieku), ale również jako znak-symbol, gdyż w tym przypadku „znaczone” są idee dotyczące przemocy, zniszczenia i śmierci w kulturze masowej. Postać Jokera nabrała dodatkowego znaczenia, gdyż to właśnie na premierze tego filmu doszło do tragicznego wydarzenia: zamachowiec (inspirowany postacią graną przez Ledgera) otworzył ogień do widzów, zabijając 12 osób. Okładka skłania czytelnika do refleksji dotyczącej treści kultury masowej (w tym kultury popularnej i przekazów medialnych) oraz eksponowania w niej przemocy i gwałtu.

„Polityka” porusza też na okładkach kwestie dotyczące współczesnego postrzegania kategorii polskości i patriotyzmu. Obie dotyczące tych problemów prezentacje nawiązują do Euro 2012, traktując tę imprezę jako czas, kiedy Polska i Polacy stają się przedmiotem zainteresowania innych państw (ich mediów) i kiedy nadarza się okazja do autorefleksji związanej z pytaniem: Jaki jest nasz stosunek do ojczyzny i narodu? Kolejny raz dostrzegalne są wyraźne różnice w sposobie komponowania okładek i pojawiających się na nich komentarzy między „Polityką” a „Uważam Rze”. 

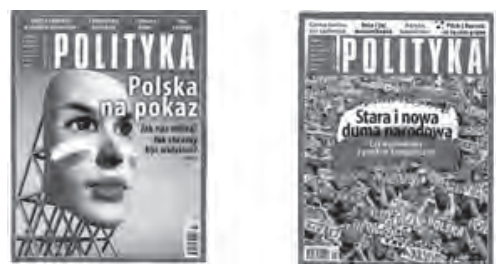

Pierwsza z okładek przypomina plakat (nr 22/2012). Widzimy na niej zamontowaną na rusztowaniu dużą maskę twarzy z pomalowanymi na czerwono ustami i biało czerwonymi flagami na policzkach (częsty „atrybut” kibica polskich reprezentacji narodowych). Maska jest wystawiona na widok innych, ma być swego rodzaju „naszym symbolem" (reklamą). Patriotyzm, polskość są więc pewnego rodzaju projektem, wypadkową naszych starań i zewnętrznych ocen. Podkreśla to tekstowe zakotwiczenie: Polska na pokaz. Jak nas widza? Jak chcemy być widziani? Nie ma w tym miejscu odwołań do przeszłości, tradycji; pytanie dotyczy przyszłości, pewnego zadania do wykonania. Dodatkowo polskość zostaje powiązana z kategorią wizerunku i tożsamości, które opierają się na kompromisie między własnymi oczekiwaniami a tym, jak określają nas inni. Druga z okładek jest zdjęciem, na którym widać tłum polskich kibiców z podniesionymi szalikami w barwach narodowych i cyfrowymi aparatami fotograficznymi (być może zdjęcie zrobiono w trakcie wykonywania przez nich hymnu narodowego). Symboliczne, samo w sobie, jest to, że szukając ilustracji dla charakteru współczesnego patriotyzmu i dumy narodowej, wybrano zdjęcie kibiców reprezentacji. Jednym z powodów mogło być to, że manifestacja „barwnego” patriotyzmu odbywa się dziś głównie w trakcie dużych imprez sportowych. Innym - wysokie oceny organizacji turnieju Euro 2012, pojawiające się już w trakcie jego trwania (opisywany numer był datowany na 13-19 czerwca). To wydarzenie sportowe symbolizowało zbiorowy wysiłek organizacyjny Polaków, miało być potwierdzeniem nowoczesności naszego państwa. Wymowny jest tu tekst na okładce: Stara i nowa duma narodowa. Czy wychodzimy z polskich kompleksów? Nowe czasy wymagają nowej polskości i nowego sposobu czerpania z niej dumy, jako konsekwencji odrzucenia polskich kompleksów. Te ostatnie nie zostają na okładce zdefiniowane (dzieje się tak w środku tygodnika), ale - odwołując się do funkcjonujących stereotypów kulturowych - odbiorca może łatwo odtworzyć ów katalog kompleksów. Próbując uogólnić rozważania związane z problemem współczesnego patriotyzmu, można powiedzieć, że dla „Polityki” to zadanie, którego rozwiązanie leży w przyszłości, natomiast w „Uważam Rze” kwestia ta jest mocno osadzona w tradycji i wymaga troski i ochrony.

\section{PODSUMOWANIE}

Przy analizie współczesnych polskich mediów wielokrotnie powraca pytanie o obiektywizm bądź bezstronność dziennikarzy czy też w ogóle nadawców medialnych (tytułów prasowych, stacji telewizyjnych). Pytanie takie zdaje się jednak źle postawione (chyba 
że chodzi nam o wymuszenie odpowiedzi zgodnej z regułami politycznej poprawności i czegoś takiego, jak etyka zawodu). Jak wskazano wcześniej, badanie nie pretenduje do uniwersalności wyprowadzonych wniosków, jednak przeprowadzona w artykule analiza pokazuje istniejące obok siebie dwa opisy rzeczywistości politycznej, z których każdy (najprawdopodobniej) w tym samym stopniu rości sobie prawo do „bycia-tym-prawdziwym”. Te dwie „opowieści o polityce” są konsekwencją dwóch różnych reżimów skopicznych, odpowiednio zróżnicowanych reżimów wytwarzania i odbioru. Zamiast więc poszukiwać obiektywizmu, być może lepsza będzie próba opisu profilu (linii) czasopisma, które oprócz transmisji wiedzy musi również rywalizować z konkurentami o czytelnika na trudnym rynku.

Tygodnik „Uważam Rze” każdorazowo na swojej okładce reklamuje się hasłem: Tygodnik Autorów Niepokornych. Sugeruje to, że projekt ten opierał się przede wszystkim na autorskim przekazie grupy dziennikarzy pozostających w opozycji zarówno do rządu, jak i (ich zdaniem) mainstreamowych przemian w świecie społecznym, politycznym czy kulturowym. Świat polityki na okładkach tej gazety jest biegunowy i dychotomiczny. Ponadto aby poznać go „naprawdę”, należy zajrzeć głębiej, pod wierzchnią warstwę wizerunkowych pozorów. Zapewne należy uwzględnić również to, że wydawanie tygodnika jest przedsięwzięciem biznesowym - okładka zaś, jak wspominano na początku, traktowana jest też jako reklama czasopisma. Dlatego nasycenie przekazu rozbudowaną symboliką i treścią pełną emocji i zaangażowania może być traktowane jako przemyślana strategia opanowania rynkowej niszy (przecież autorzy „Uważam Rze” za rządów Prawa i Sprawiedliwości znajdowali się na eksponowanych stanowiskach w jak najbardziej mainstreamowych mediach). „Uważam Rze” (do pewnego momentu) był bowiem jedynym tygodnikiem konserwatywnym, zdecydowanie krytycznym wobec rządu PO-PSL, podejmującym temat katastrofy smoleńskiej, wedle umownych kategorii również prawicowym. Inaczej jest w przypadku „Polityki”; to tytuł o długiej tradycji (wydawany od 1957 r.) i ugruntowanej pozycji na rynku. Można przyjąć, że radykalizacja komunikatów, zaangażowanie emocjonalne nie są tej gazecie (jej autorom i wydawcom) potrzebne. Styl prezentowania kwestii i problemów politycznych na okładkach tego tytułu jest inny niż w „Uważam Rze”. Nie ma tam bardzo wyraźnego opowiedzenia się po stronie rządu czy opozycji, choć trudno uznać „Politykę” za sympatyzującą z Prawem i Sprawiedliwością („niepokorni” autorzy do dziś pamiętają tygodnikowi okładkę Tusku musisz! jednego z październikowych numerów w 2007 r.).

Prezentacja rzeczywistości politycznej na okładkach tygodników wpisuje się w kształtujące się obecnie (nowe) podziały socjopolityczne, będące następstwem tych dokonujących się od początku lat 90., związanych z pragmatyczną wizją polityki i rządzenia państwem, oraz zakorzenieniem działania politycznego w określonym zestawie wartości.

Każdy z tytułów w inny, charakterystyczny sposób, przez użycie określonych symboli, tworzy odmienny rodzaj semantycznej i semiotycznej koherencji, czyli, mówiąc inaczej, dokonuje scalania wiedzy między środowiskiem dziennikarzy a czytelnikami danej gazety. Na podstawie przeprowadzonej analizy należy stwierdzić, że podstawy i granice wytwarzanej wspólnoty wartości są wyraźniejsze na okładkach „Uważam Rze”. Ten tygodnik, pomyślany w dużej mierze jako polityczna deklaracja i autorska propo- 
zycja opisu świata polityki, tego rodzaju założenia miał wpisane niejako w swą fundatorską formułę. Tym bardziej interesujące jest, jak będzie funkcjonował ten tytuł po zmianie redaktora naczelnego i odejściu wielu kluczowych dziennikarzy w wyniku tzw. afery trotylowej związanej z publikacją w „Rzeczypospolitej”, a także po powstaniu nowego tytułu: „W Sieci”, założonego przez Michała Karnowskiego (byłego dziennikarza „Uważam Rze”). Ciekawe również, na ile tygodnik, po praktycznie całkowitej zmianie, jeśli chodzi o skład redakcji i publikujących tam autorów, będzie zainteresowany i wiarygodny w utrzymywaniu swej dotychczasowej linii. Uwagi dotyczące podsumowania analiz należy więc odnosić do przebadanego okresu, pozostając ostrożnym w przenoszeniu wniosków na numery ukazujące się po głębokich zmianach w „Uważam Rze”.

„Polityka” wydaje się przesuwać w stronę social magazine. Akcentuje na swych okładkach głównie bieżące wydarzenia, często podejmuje problematykę społeczną. W analizach nie widać tak wyraźnych, jak w „Uważam Rze”, prób określania świata wartości czytelników. „Polityka” stara się być pragmatyczna i inkluzywna (choć wskazuje na świat PiS i podziałów, np. wokół Radia Maryja), „Uważam Rze” na swych okładkach akcentuje kwestie polityczne i ekskluzywność środowiska, dla którego konstruuje swój przekaz i buduje określony obraz rzeczywistości. W „Polityce” więcej jest policy, zaś w „Uważam Rze” dominuje politics; inaczej mówiąc: jeden z tygodników odnosi się częściej do bieżących wydarzeń i problemów społecznych, drugi zrobił zdecydowany krok „w stronę polityki” i kwestii konkurencji w tym polu.

Każdy z tygodników wytarza określony system logonomiczny ${ }^{17}$, przez co patrzący na ich okładki (a niekiedy i czytający tytuły) zostaje zapoznany z określonym systemem znaczeń. Inicjatorami znaczeń są w tym przypadku wydawcy, którzy przy pomocy grafików, czy też sięgając do swej biblioteki zdjęć, prezentują w zamierzony sposób postaci, wydarzenia czy idee. Okładki można wielokrotnie uznać za przesycone symboliką, której wymowa zostaje dopasowana do wyobrażonego odbiorcy danego komunikatu. Aby bowiem móc poprawnie odczytać znaczenia, trzeba właściwie odkodować obecne na okładkach systemy znaków, umiejętnie odnieść je do skonwencjonalizowanych znaczeń, skonfrontować obraz z proponowanym tekstowym zakotwiczeniem. Zasady logonomiczne, które mają wzmacniać dążenie do jednoznacznej bądź właściwej hierarchii znaczeń w przypadku polisemii, pozostają pod kontrolą konkretnych czynników społecznych - mediów i organizujących medialne urządzanie społeczeństwa właścicieli, wydawców i dziennikarzy. Przykładowo „Uważam Rze” silnie wierzy w dużą moc sprawczą (i wiążącą się z tym odpowiedzialność) kluczowych aktorów politycznych. Dlatego winny wszelkim dostrzeganym przez ten tytuł niepowodzeniom jest premier rządu (choć w jednym przypadku negatywna rola przypada choremu systemowi). Na okładkach da się również dostrzec tęsknotę za mężem stanu, który byłby godny przewodzenia takiemu narodowi, jakim są Polacy. W „Polityce” częściej zwraca się uwagę na procesy kulturowe, ich dużą siłę i nieuchronność. Rola polityków staje się dziś ograniczona, a rodzaj relacji łączącej ich z obywatelami zmierza od wspólnoty wartości i emocjonalnego zaangażowania ku kontraktowi i transakcyjnej formule.

17 G. Rose, dz. cyt., s. 129-130. 
Dwa tygodniki konstruują na swych okładkach dwa odmienne reżimy skopiczne, w różny sposób opisując wydarzenia polityczne, głównych polityków, problemy społeczne czy sytuację na rynku mediów. Obecnie na konkurencyjnym rynku mediów i funkcjonujących w społeczeństwie różnych światów społecznych (skupionych wokół podobnych wartości, styków życia, ideologii) taka sytuacja wydaje się naturalna. Chodzi przecież o to, aby redakcja i czytelnicy podzielali wspólny sens i proponowany opis rzeczywistości. Jednak światy te zaczynają funkcjonować coraz bardziej obok siebie, traktując przekazy konkurencji jako blade tło, na którym jaskrawo odznacza się profesjonalizm, obiektywizm i przenikliwość „naszego” spojrzenia.

\section{BIBLIOGRAFIA}

Barthes R., Światto obrazu. Uwagi o fotografii, przel. J. Trznadel, Warszawa 2008.

Berger P., Zaproszenie do socjologii, przeł. J. Stawiński, Warszawa 1995.

Berger P., Luckmann T., Spoteczne tworzenie rzeczywistości. Traktat z socjologii wiedzy, przeł. i przedm. J. Niżnik, Warszawa 2010, Biblioteka Socjologiczna.

van Dijk T. A., Badania nad dyskursem, [w:] Dyskurs jako struktura i proces, red. T. A. van Dijk, wybór i przeł. G. Grochowski, red. nauk. T. Dobrzyńska, Warszawa 2001.

Gadacz T., Historia filozofii XX wieku. Nurty, t. 1: Filozofia życia, pragmatyzm, filozofia ducha, Kraków 2010.

Hall S., Kodowanie i dekodowanie, „Przekazy i Opinie” 1987, nr 1-2.

Konecki K. T., Wizualne wyobrażenia. Gtówne strategie badawcze w socjologii wizualnej a metodologia teorii ugruntowanej, „Przegląd Socjologii Jakościowej” 2005, t. 1, nr 1.

MacGregor Burns J., Wtadza przywódcza, [w:] Wtadza i spoteczeństwo. Antologia tekstów z zakresu socjologii polityki, t. 1, wybór i oprac. J. Szczupaczyński, Warszawa 1995.

McCombs M., Ustanawianie agendy. Media masowe i opinia publiczna, przeł. B. Radwan, Kraków 2008, Media - Wydawnictwo Uniwersytetu Jagiellońskiego.

Park R. E., News As a Form of Knowledge: A Chapter in the Sociology of Knowledge, „The American Journal of Sociology" 1940, Vol. 45, nr 5.

Rose G., Interpretacja materiatów wizualnych. Krytyczna metodologia badań nad wizualnościa, przeł. E. Klekot, Warszawa 2010, Metodologia - Wydawnictwo Naukowe PWN.

Silverman D., Interpretacja danych jakościowych. Metody analizy rozmowy, tekstu i interakcji, przeł. M. Głowacka-Grajper, J. Ostrowska, wprow. K. T. Konecki, Warszawa 2007.

Dr Marcin KOTRAS, doktor nauk humanistycznych, adiunkt w Katedrze Socjologii Polityki i Moralności w Instytucie Socjologii Uniwersytetu Łódzkiego. Swoje zainteresowania badawcze koncentruje na języku polityki i procesach instytucjonalizacji w obszarach politycznych (od szczebla samorządowego do ponadnarodowego). Autor książki Przywództwo polityczne na poziomie regionu. Przyktad województwa tódzkiego (Łódź 2009). Redaktor prowadzący w czasopiśmie „Władza sądzenia” i sekretarz redakcji „Folia Sociologica”. 